\title{
Multi-analytical identification of pigments and pigment mixtures used in 17 th century Portuguese azulejos
}

\author{
Susana Coentro $^{\mathrm{a}, \mathrm{b}, \mathrm{c}}$, João M. Mimoso ${ }^{\mathrm{d}}$, Augusta M. Lima ${ }^{\mathrm{a}, \mathrm{b}}$, António S. Silva ${ }^{\mathrm{d}}$, \\ Alexandre N. Pais ${ }^{\mathrm{e}}$, Vânia S.F. Muralha ${ }^{\mathrm{a}, *}$ \\ ${ }^{a}$ Research Unit VICARTE: Vidro e Cerâmica para as Artes, Faculdade de Ciências e Tecnologia, Universidade Nova de Lisboa, 2829-516 Caparica, Portugal \\ ${ }^{\mathrm{b}}$ Departamento de Conservação e Restauro, Faculdade de Ciências e Tecnologia, Universidade Nova de Lisboa, 2829-516 Caparica, Portugal \\ ${ }^{\mathrm{c}}$ Departamento de Física, Instituto Tecnológico e Nuclear, Estrada Nacional 10, 2686-953 Sacavém, Portugal \\ ${ }^{\mathrm{d}}$ Laboratório Nacional de Engenharia Civil (LNEC), Av. do Brasil, 101, 1700-066 Lisboa, Portugal \\ ${ }^{\mathrm{e}}$ Museu Nacional do Azulejo, Rua da Madre de Deus, 4, 1900-312 Lisboa, Portugal \\ Received 5 May 2011; received in revised form 11 July 2011; accepted 21 July 2011 \\ Available online 23 August 2011
}

\begin{abstract}
A multi-analytical approach was used to study the pictorial layers of a set of 17th century historic glazed tiles (azulejos) of Portuguese manufacture. The pictorial layer was studied by $\mu$-EDXRF, $\mu$-Raman, SEM-EDS and OM. Although the established palette comprises few pigments, it was found that the tiles were enhanced by the use of pigment mixtures, which were identified by $\mu$-Raman and $\mu$-EDXRF. As expected, the blue colour derives from cobalt oxide, purple from manganese oxide and emerald-green from copper oxide. Regarding the yellow pigment, $\mu$-Raman results show it is consistent with the composition of a ternary oxide, whereas $\mu$-EDXRF shows a high intensity of $\mathrm{Zn}$ in this colour, indicating a composition close to a $\mathrm{Pb}-\mathrm{Sb}-\mathrm{Zn}$ ternary oxide. Some compounds from the original ores were also indentified: in two very dark blue samples, cobalt and nickel olivines $\left(\alpha-\mathrm{Co}_{2} \mathrm{SiO}_{4}, \alpha-\mathrm{Ni}_{2} \mathrm{SiO}_{4}\right)$, and in a dark brown sample, braunite (a manganese silicate).
\end{abstract}

(C) 2011 Elsevier Ltd. All rights reserved.

Keywords: 17th century majolica; Glazed tiles (azulejos); Pigments; Glaze analysis

\section{Introduction}

When visiting Portugal, one cannot overlook the ever-present azulejo panels decorating many buildings and public spaces. Azulejos are considered the most important historic Portuguese decorative art, having been used without interruption for more than five centuries. ${ }^{1,2}$

Azulejos is the Portuguese name for ceramic glazed tiles. Their local use may have started as early as the 13th century entering Portugal through Moorish influence. ${ }^{3}$ The majolica technique was adopted in the second half of the 16th century and, possibly through the activity of Flemish and Italian artists in Portugal, provided the ground for the creation of impressive figurative panels which can still be seen today. ${ }^{1}$ In the first half of the 17 th century, the country was undergoing a political transition derived from the coronation of Philip II of Spain as the

\footnotetext{
* Corresponding author. Tel.: +351 212947893

E-mail address: solange@fct.unl.pt (V.S.F. Muralha).
}

Portuguese king by right of inheritance. The court was now set in Madrid and that caused an economic and artistic decline in Portugal. Consequently the azulejo evolved, possibly because of its gaudiness, as the chosen material to decorate an otherwise plain architecture, substituting the rich oriental embroider draperies that once hanged from the walls of churches. ${ }^{2}$ Being a relatively cheap but durable material, decorative tiles could be manufactured and painted by unskilled craftsmen in large quantities to cover entire walls. Pattern tiles (often called "tapestry" tiles) were especially important in this context, first mimicking tapestries and then evolving gradually over time towards more complex and novel patterns. ${ }^{2}$ The decorative effect was striking and monumental.

It was also in the 17th century that the chromatic palette of the Portuguese tile makers reached a peak before decreasing progressively to the blue-and-white period that had set by the end of the century. Colours were applied over a white lead-tin majolica glaze and comprised blue, yellow, oranges, greens, purple, browns and a very dark, almost-black colour used for contours. The lead-tin glaze was applied over the previously 
fired ceramic body and the decorative motifs were painted before firing the glaze. Colours were obtained through metal oxides (copper, manganese, cobalt, iron) or synthesized pigments (Naples Yellow), which were used singly or mixed with other pigments.

Despite the importance of the azulejo heritage, relatively few scientific studies concerning its materials have been published. $^{4-9}$ However, studies on other sorts of majolica have also been a valuable source of information about the materials and techniques used in the 16 th and 17 th centuries. ${ }^{10-13}$ The yellow pigment has been widely investigated in the last decade after the identification of a Naples Yellow variant - the $\mathrm{Pb}-\mathrm{Sb}-\mathrm{Sn}$ ternary oxide - by Roy and Berrie. ${ }^{14}$ Cobalt blue has been also the subject of several provenance studies. ${ }^{15-17}$

This work aimed at the identification of the pigments and pigment mixtures used to produce the colours of 17 th century azulejos, as a first step to understand the production technology of the Portuguese azulejo manufacturers. A multi-analytical approach was used to chemically characterize the pigments responsible for the observed colours. Non-destructive analytical techniques, such as $\mu$-Raman and $\mu$-EDXRF, were favoured. Results are systematized by the most representative colours, and compared with the production technology described in the wellknown majolica treatise from the 16th century, "The Three Books of the Potter's Art" by Cipriano Piccolpasso. ${ }^{18}$

\section{Experimental}

\subsection{Samples}

A set of 28 fragments of 17 th century Portuguese glazed ceramic tiles was studied. The samples were provided by the National Tile Museum (Museu Nacional do Azulejo) in Lisbon, and a few samples came from private collections. Fig. 1 shows some samples where all the representative colours are depicted.

Table 1 includes a full list of the analysed samples, with the colours observed for each and the respective analytical techniques used. The basic criteria for the analysis was having a representative group of samples for each colour, taking into consideration the tonal variations, and the possibility of studying each colour individually, avoiding areas of superposition.

\subsection{Analytical techniques}

\subsubsection{SEM-EDS}

A JEOL JSM-6400 with an Oxford Instruments microanalysis unit equipped with a $\mathrm{Si}(\mathrm{Li}) \mathrm{X}$-ray detector was used. Polished cross-sections were prepared by impregnating samples with an epoxy resin, polishing them to $3 \mu \mathrm{m}$ and applying a graphite coating.

\subsection{2. $\mu-E D X R F$}

Analyses were carried out using an ArtTAX spectrometer (Intax $\mathrm{GmbH}$ ), with a Mo anode and an XFlash ${ }^{\circledR}$ detector. The measurement parameters were: $40 \mathrm{kV}$ of voltage and $600 \mu \mathrm{A}$ of current under a He atmosphere. Spectra of white and blue glazes were acquired in three different locations for $360 \mathrm{~s}$, whilst for
Table 1

List of samples analysed, the colours identified and the respective analytical techniques used on each colour.

\begin{tabular}{|c|c|c|c|c|}
\hline \multirow[t]{2}{*}{ Sample } & \multirow[t]{2}{*}{ Colours $^{\mathrm{a}}$} & \multicolumn{3}{|c|}{ Performed analysis } \\
\hline & & $\mu$-EDXRF & $\mu$-Raman & SEM-EDS \\
\hline SCT02 & $\mathrm{B}, \mathrm{Y}, \mathrm{O}$ & $X$ & $\mathrm{X}$ & \\
\hline SCT03 & $\mathrm{B}, \mathrm{Y}, \mathrm{O}$ & $\mathrm{X}$ & $\mathrm{X}$ & \\
\hline SCT05 & $\mathrm{B}, \mathrm{Y}, \mathrm{O}$ & $\mathrm{X}$ & $\mathrm{X}$ & $X$ \\
\hline SCT07 & $\mathrm{B}, \mathrm{O}$ & $\mathrm{X}$ & & \\
\hline SCT08 & $\mathrm{B}, \mathrm{Y}, \mathrm{O}$ & $\mathrm{X}$ & $\mathrm{X}$ & \\
\hline SCT10 & $\mathrm{B}, \mathrm{Y}, \mathrm{EG}, \mathrm{P}$ & $\mathrm{X}$ & $\mathrm{X}$ & $\mathrm{X}$ \\
\hline SCT12 & $\mathrm{B}, \mathrm{Y}, \mathrm{O}, \mathrm{OG}$ & $\mathrm{X}$ & & \\
\hline SCT13 & $\mathrm{B}, \mathrm{Y}, \mathrm{O}, \mathrm{OG}$ & $\mathrm{X}$ & $\mathrm{X}$ & $\mathrm{X}$ \\
\hline SCT14 & $\mathrm{B}, \mathrm{Y}$ & $\mathrm{X}$ & $\mathrm{X}$ & $\mathrm{X}$ \\
\hline SCT15 & $\mathrm{B}, \mathrm{Y}$ & $\mathrm{X}$ & & \\
\hline SCT16 & $\mathrm{B}, \mathrm{Y}$ & $\mathrm{X}$ & & \\
\hline SCT17 & $\mathrm{B}, \mathrm{Y}$ & $\mathrm{X}$ & $\mathrm{X}$ & \\
\hline SCT18 & $\mathrm{B}, \mathrm{Y}$ & $\mathrm{X}$ & & \\
\hline SCT19 & $\mathrm{B}, \mathrm{Y}$ & $\mathrm{X}$ & & \\
\hline SCT20 & $\mathrm{B}, \mathrm{Y}$ & $\mathrm{X}$ & $\mathrm{X}$ & $\mathrm{X}$ \\
\hline SCT21 & $\mathrm{B}, \mathrm{Y}, \mathrm{O}, \mathrm{OG}$ & $\mathrm{X}$ & & \\
\hline SCT23 & $\mathrm{B}, \mathrm{Y}, \mathrm{O}$ & $\mathrm{X}$ & & \\
\hline SCT25 & $\mathrm{B}, \mathrm{Y}, \mathrm{O}$ & $\mathrm{X}$ & $\mathrm{X}$ & \\
\hline SCT27 & $\mathrm{B}, \mathrm{Y}, \mathrm{P}$ & $\mathrm{X}$ & $\mathrm{X}$ & $\mathrm{X}$ \\
\hline SCT29 & $\mathrm{B}, \mathrm{Y}, \mathrm{EG}, \mathrm{P}$ & $\mathrm{X}$ & & \\
\hline SCT31 & $\mathrm{B}, \mathrm{P}$ & $X$ & $\mathrm{X}$ & \\
\hline SCT32 & $\mathrm{B}, \mathrm{Y}$ & $\mathrm{X}$ & & \\
\hline SCT34 & $\mathrm{B}, \mathrm{Y}, \mathrm{EG}, \mathrm{P}$ & $\mathrm{X}$ & & \\
\hline SCT35 & $\mathrm{Y}, \mathrm{OG}, \mathrm{P}$ & $\mathrm{X}$ & & \\
\hline SCT36 & $\mathrm{Y}, \mathrm{P}$ & $\mathrm{X}$ & & \\
\hline SCT37 & $\mathrm{B}, \mathrm{Y}, \mathrm{O}, \mathrm{OG}$ & $\mathrm{X}$ & & \\
\hline SCT38 & $\mathrm{B}, \mathrm{Y}, \mathrm{O}$ & $\mathrm{X}$ & & \\
\hline SCT39 & $\mathrm{B}, \mathrm{Y}, \mathrm{O}$ & $X$ & & \\
\hline
\end{tabular}

a Caption: B, blue; Y, yellow; O, orange; OG, olive-green; EG, emerald-green; $\mathrm{P}$, purple/brown.

the other colours the measurement time was of $180 \mathrm{~s}$ and the number of spectra varying between two to three per colour.

Semi-quantitative analysis of the white glaze was performed using WinAxil and WinFund softwares. A reference lead-tin glass was synthesized as a reference. The accuracy of the method was calculated using the glass standard CMOG C (The Corning Museum of Glass). The accuracy of the method was $<5 \%$ for $\mathrm{SiO}_{2}$ and $\mathrm{PbO},<10 \%$ for $\mathrm{K}_{2} \mathrm{O}$ and $\mathrm{SnO}_{2},<20 \%$ for $\mathrm{MnO}, \mathrm{CaO}$, $\mathrm{CoO}, \mathrm{NiO}, \mathrm{CuO}$ and $\mathrm{ZnO}$, and $<50 \%$ for $\mathrm{Al}_{2} \mathrm{O}_{3}, \mathrm{TiO}_{2}, \mathrm{Fe}_{2} \mathrm{O}_{3}$ and $\mathrm{As}_{2} \mathrm{O}_{3}$. Relative standard deviation is $<10 \%$ for $\mathrm{SiO}_{2}, \mathrm{~K}_{2} \mathrm{O}$ and $\mathrm{PbO},<15 \%$ for $\mathrm{MnO}, \mathrm{CaO}$ and $\mathrm{Fe}_{2} \mathrm{O}_{3},<25 \%$ for $\mathrm{Al}_{2} \mathrm{O}_{3}$, $\mathrm{As}_{2} \mathrm{O}_{3}, \mathrm{CuO}$ and $\mathrm{SnO}_{2}$, and $<40 \%$ for $\mathrm{TiO}_{2}, \mathrm{CoO}$ and $\mathrm{NiO}$. The analyses of the blue, yellow and orange colours were carried out calculating the peak intensities of the elements ( $\mathrm{K} \alpha$ for $\mathrm{Co}$, $\mathrm{Ni}, \mathrm{Fe}, \mathrm{As}, \mathrm{Zn}$ and $\mathrm{L} \alpha$ for $\mathrm{Sn}, \mathrm{Sb}$ and $\mathrm{Pb}$ ), using the WinAxil software.

\subsection{3. $\mu$-Raman}

The equipment used was a Labram 300 Jobin Yvon spectrometer, equipped with a $\mathrm{He}-\mathrm{Ne}$ laser of $17 \mathrm{~mW}$ power operating at $632.8 \mathrm{~nm}$ and a solid state laser of $500 \mathrm{~mW}$ power operating at $532 \mathrm{~nm}$. The laser beam was focused with a $50 \times$ Olympus objective lens. The laser energy was filtered at $10 \%$ using a neutral density filter for all analyses. 
Table 2

Chemical composition of the white glaze (wt\%) determined by $\mu$-EDXRF

\begin{tabular}{|c|c|c|c|c|c|c|c|c|c|c|c|c|c|c|}
\hline & $\mathrm{Al}_{2} \mathrm{O}_{3}$ & $\mathrm{SiO}_{2}$ & $\mathrm{~K}_{2} \mathrm{O}$ & $\mathrm{CaO}$ & $\mathrm{TiO}_{2}$ & $\mathrm{MnO}$ & $\mathrm{Fe}_{2} \mathrm{O}_{3}$ & $\mathrm{CoO}$ & $\mathrm{NiO}$ & $\mathrm{CuO}$ & $\mathrm{ZnO}$ & $\mathrm{As}_{2} \mathrm{O}_{3}$ & $\mathrm{SnO}_{2}$ & $\mathrm{PbO}$ \\
\hline SCT07 & 0.47 & 64.7 & 6.10 & 1.17 & 0.30 & 0.01 & 0.30 & 0.06 & 0.08 & 0.04 & 0.02 & 0.23 & 2.84 & 23.8 \\
\hline SCT08 & 0.60 & 67.0 & 6.05 & 0.90 & 0.12 & 0.02 & 0.34 & 0.01 & 0.01 & 0.03 & 0.48 & 0.21 & 5.50 & 18.7 \\
\hline SCT12 & 0.50 & 65.3 & 5.60 & 0.83 & 0.08 & 0.03 & 0.25 & 0.03 & 0.03 & 0.04 & 1.20 & 0.15 & 4.73 & 21.1 \\
\hline SCT13 & 0.40 & 63.3 & 5.43 & 1.33 & 0.12 & 0.02 & 0.31 & 0.02 & 0.02 & 0.03 & 0.37 & 0.17 & 5.77 & 22.5 \\
\hline SCT15 & 0.53 & 58.0 & 6.23 & 0.97 & 0.20 & 0.03 & 0.43 & 0.07 & 0.07 & 0.04 & 1.40 & 0.29 & 5.60 & 26.2 \\
\hline SCT16 & 0.50 & 72.0 & 9.97 & 2.00 & 0.23 & 0.04 & 0.37 & 0.09 & 0.04 & 0.02 & 0.16 & 0.21 & 1.60 & 13.0 \\
\hline SCT17 & 0.42 & 69.0 & 7.77 & 1.87 & 0.29 & 0.03 & 0.43 & 0.16 & 0.15 & 0.02 & 0.09 & 0.17 & 3.08 & 16.5 \\
\hline SCT18 & 0.60 & 68.3 & 9.03 & 1.57 & 0.34 & 0.03 & 0.40 & 0.04 & 0.07 & 0.02 & 0.27 & 0.21 & 3.33 & 15.8 \\
\hline SCT21 & 0.38 & 62.0 & 3.53 & 1.13 & 0.17 & 0.02 & 0.25 & 0.01 & 0.01 & 0.11 & 1.00 & 0.13 & 3.63 & 28.0 \\
\hline SCT23 & 0.47 & 63.7 & 7.60 & 1.43 & 0.37 & 0.03 & 0.33 & 0.04 & 0.04 & 0.05 & 0.21 & 0.27 & 7.10 & 18.5 \\
\hline SCT25 & 0.40 & 59.0 & 4.27 & 0.51 & 0.11 & 0.02 & 0.22 & 0.07 & 0.01 & 0.13 & 0.90 & 0.12 & 1.91 & 32.2 \\
\hline SCT29 & 0.35 & 63.5 & 7.50 & 1.95 & 0.22 & 0.04 & 0.39 & 0.01 & 0.01 & 0.11 & 0.26 & 0.14 & 2.81 & 22.9 \\
\hline SCT31 & 0.43 & 59.7 & 5.77 & 1.37 & 0.16 & 0.04 & 0.34 & 0.03 & 0.02 & 0.08 & 0.02 & 0.16 & 2.66 & 29.3 \\
\hline SCT37 & 0.53 & 67.3 & 7.20 & 0.77 & 0.22 & 0.01 & 0.34 & 0.29 & 0.01 & 0.01 & 0.43 & 0.15 & 4.73 & 17.9 \\
\hline SCT38 & 0.50 & 66.7 & 6.50 & 1.13 & 0.11 & 0.02 & 0.31 & 0.04 & 0.04 & 0.07 & 0.21 & 0.23 & 5.37 & 18.9 \\
\hline SCT39 & 0.43 & 64.0 & 9.47 & 4.50 & 0.18 & 0.04 & 0.45 & 0.09 & 0.05 & 0.02 & 0.24 & 0.24 & 2.57 & 17.6 \\
\hline
\end{tabular}
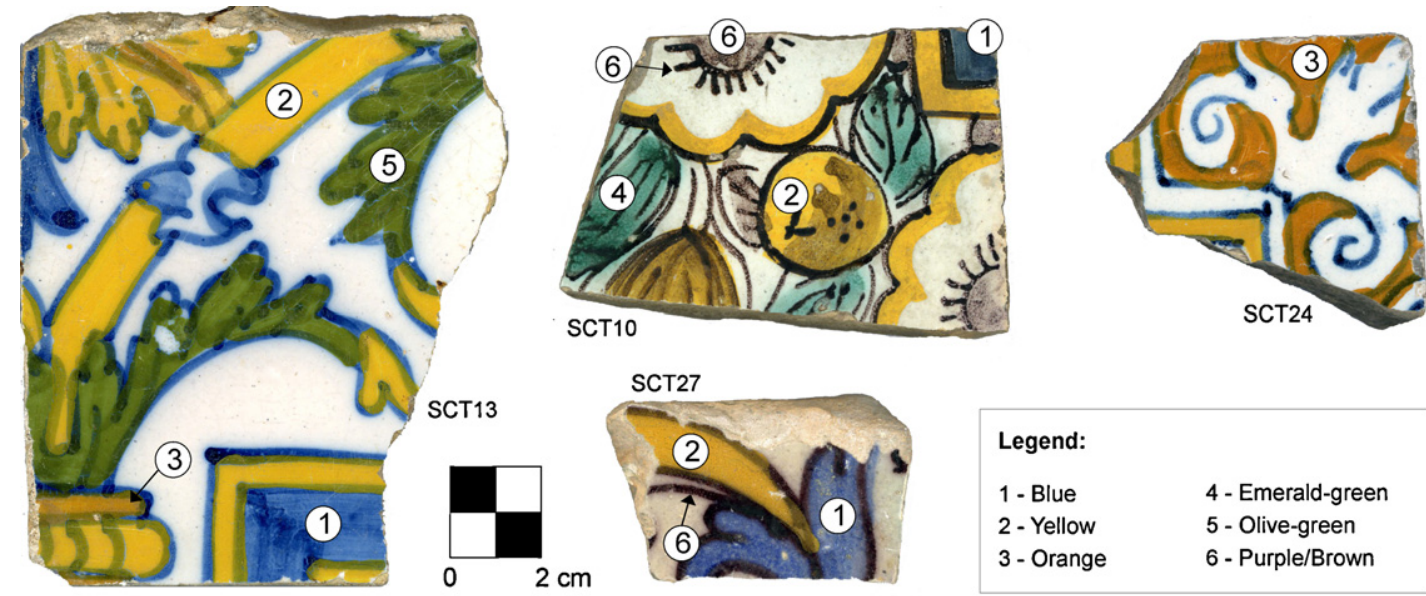

Fig. 1. Analysed colours in 17th century Portuguese azulejos, exemplified with four samples. (For interpretation of the references to color in this figure legend, the reader is referred to the web version of the article.)

\subsubsection{Optical microscopy}

A Zeiss Axioplan 2 optical microscope, equipped with a high resolution camera Nikon DXM 1200F.

\subsubsection{Binocular lens}

Polished cross-sections were observed through an Olympus SZH binocular lens, with digital image capture.

\section{Results and discussion}

\subsection{White glaze}

The study of the white glaze was very important to understand the Portuguese tile production technology. SEM observations of polished cross-sections of the tiles showed a heterogeneous glaze with several mineral inclusions and gas bubbles. Mineral inclusions can be relatively large (ca. 20-100 $\mu \mathrm{m}$ ), and consist mainly of quartz and potassium feldspars, according to results obtained from SEM-EDS (Fig. 2a and b) and $\mu$-Raman analysis (Fig. 3). They may be associated with sand used as a raw mate- rial for the glaze manufacture. The coarse granulometry may be explained through economic factors: a faster production would be cheaper but simultaneously, those inclusions contribute to the opacification of the glaze and hence reduce the amount of $\mathrm{SnO}_{2}$ needed to cloak the biscuit. ${ }^{19}$ Cassiterite $\left(\mathrm{SnO}_{2}\right)$ crystals were identified in situ by $\mu$-Raman microscopy and observed through SEM as small agglomerates.

The high lead content of the glaze gives it a much brighter appearance than the ceramic body in backscattered SEM images (BSE) and a clear interface between the two components of the tile, resulting from the double firing, is evident. The glaze thickness of the 28 samples varies between 300 and $500 \mu \mathrm{m}$ with some in-tile spread due to irregularities in the surface of the ceramic body.

Semi-quantitative chemical analysis by $\mu$-EDXRF revealed relatively high contents of $\mathrm{SiO}_{2}(58.0-72.0 \mathrm{wt} \%)$ and relatively low contents of $\mathrm{PbO}$ (13.0-32.2 wt\%) when compared to other international studies on majolica. ${ }^{12,13}$ Variations in $\mathrm{SnO}_{2}$ content (1.60-7.10 wt\%) reflect the glaze appearance: samples with $>5 \mathrm{wt} \% \mathrm{SnO}_{2}$ content show a more homogeneous and opaque 

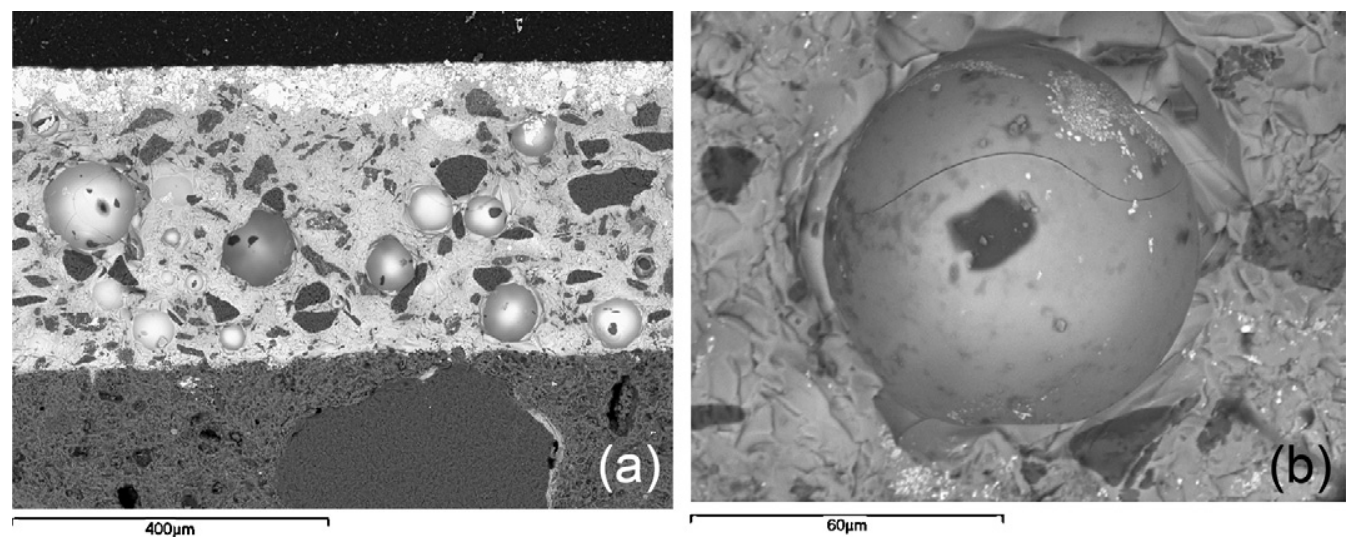

Fig. 2. Backscattering images of cross-sections of the majolica glazes: (a) white glaze of sample SCT27, showing large gas bubbles and several mineral inclusions. At the surface, the lead-rich yellow pigment layer stands out; (b) enlarged image, showing a gas bubble and cassiterite crystals.

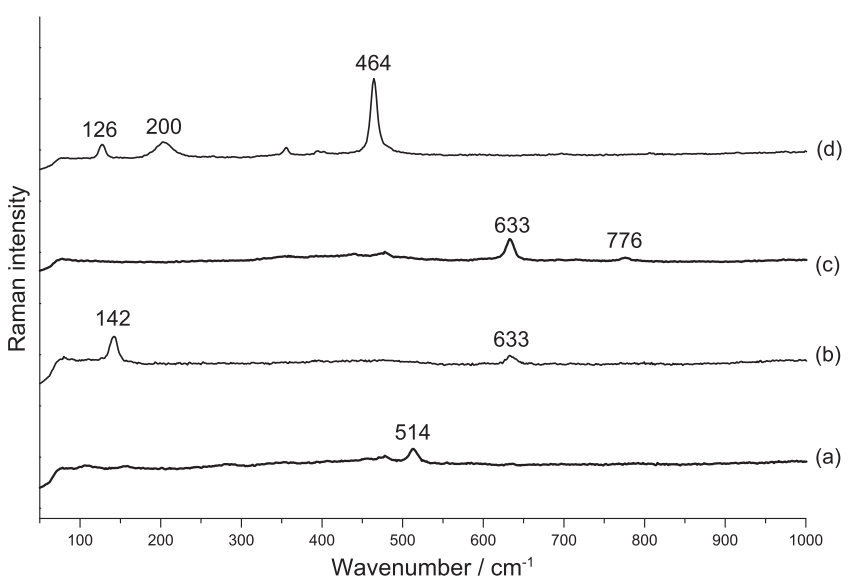

Fig. 3. $\mu$-Raman spectra of (a) potassium feldspar, (b) anatase, (c) cassiterite and (d) quartz identified in situ on the white glaze. Laser excitation $632.8 \mathrm{~nm}$; $50 \times$ objective ULWD; laser power was kept at $1 \mathrm{~mW}$.

glaze with a purer white colour. Results of the semi-quantitative analysis are summarized in Table 2.

"Irregular" and "heterogeneous" are two appropriate words to describe the white glaze in 17th century Portuguese azulejos. They were supposed to be a cheap decorative finishing and therefore the production technique was far less refined than what was used on European decorated glazed earthenware. The tiles were manufactured in large quantities and were not works of art by themselves, since they were not to be taken individually as artistic objects, like Italian majolica works. The artistic value rests on the panels and on their often inextricable interconnection with architecture.

\subsection{Blue colour}

$\mu$-EDXRF analysis of the blue decoration revealed, as expected, cobalt oxide as the colouring agent. Cobalt ions are well diffused throughout the glaze matrix revealing a very homogenous layer (Fig. 4a). $\mu$-Raman analyses on several of the blue samples, and collected at different depths, returned the Raman signatures of $\mathrm{SnO}_{2}$ and $\alpha$-quartz, in the glaze matrix. None of the spectra collected could be associated with the blue
Table 3

Chemical composition of each colour.

\begin{tabular}{ll}
\hline Colours & Chemical composition \\
\hline "Simple" colours & \\
Blue & Cobalt oxide \\
& SCT 20, SCT 32: $\alpha-\mathrm{Co}_{2} \mathrm{SiO}_{4}, \alpha-\mathrm{Ni}_{2} \mathrm{SiO}_{4}$ \\
Purple/brown & Manganese oxide \\
Emerald-green & Copper oxide \\
Yellow & Yellow ternary oxide of $\mathrm{Pb}-\mathrm{Sb}-\mathrm{Zn}(?)$ \\
"Mixed" colours & \\
Orange & Yellow ternary oxide of $\mathrm{Pb}-\mathrm{Sb}-\mathrm{Zn}(?)+\alpha-\mathrm{Fe}_{2} \mathrm{O}_{3}$ \\
Olive-green & Yellow ternary oxide of $\mathrm{Pb}-\mathrm{Sb}-\mathrm{Zn}(?)+$ cobalt oxide \\
Dark-brown & Manganese oxide $+\alpha-\mathrm{Fe}_{2} \mathrm{O}_{3}$ \\
& SCT 10, SCT 27, SCT 36: $\left(\left(\mathrm{Mn}^{2+}\right.\right.$, \\
& $\left.\mathrm{Mn}^{3+}\right)_{6} \mathrm{O}_{8} \mathrm{SiO}_{4}+\alpha-\mathrm{Fe}_{2} \mathrm{O}_{3}$ \\
\hline
\end{tabular}

pigment. On the other side, the $\mathrm{Si}-\mathrm{O}$ stretching and bending envelopes typical of glass structures were often identified.

To gather further information on the chemical composition of the blue pigment, the $\mu$-EDXRF spectrum of the white glaze was subtracted from that of the blue glaze. This procedure enables isolating the contribution of the blue colour, ${ }^{12,16}$ and allows the comparison between peak intensities without the interference of the chemical composition of the white glaze matrix.

Our results show a blue pigment characterized by an association $\mathrm{Co}-\mathrm{Fe}-\mathrm{Ni}-\mathrm{As}$. A small peak intensity of $\mathrm{Mn}$ was also detected and, in some samples, $\mathrm{Zn}$ and $\mathrm{Cu}$. The $\mathrm{Co}-\mathrm{Fe}-\mathrm{Ni}-\mathrm{As}$ association is consistent with saffre $\mathrm{f}^{\mathrm{f}}$ exported from the district of Schneeberg (in the Erzgebirge region in Germany), to the rest of Europe since the 16th century. ${ }^{15,17}$ There is a documented evidence of Portuguese trade of saffre from Germany, dating from the beginning of the 16th century. ${ }^{20}$ However, other possible sources of the pigment cannot be excluded. In the Iberian Peninsula, a well-documented site of cobalt production is Teruel, in Spain, although its mines were of limited size. ${ }^{17,21,22}$ The most common cobalt minerals include arsenic and sometimes sulphur in their composition. In sulpho-arseniates, Co can be replaced

\footnotetext{
${ }^{\text {f }}$ A calcinated cobalt ore.
} 

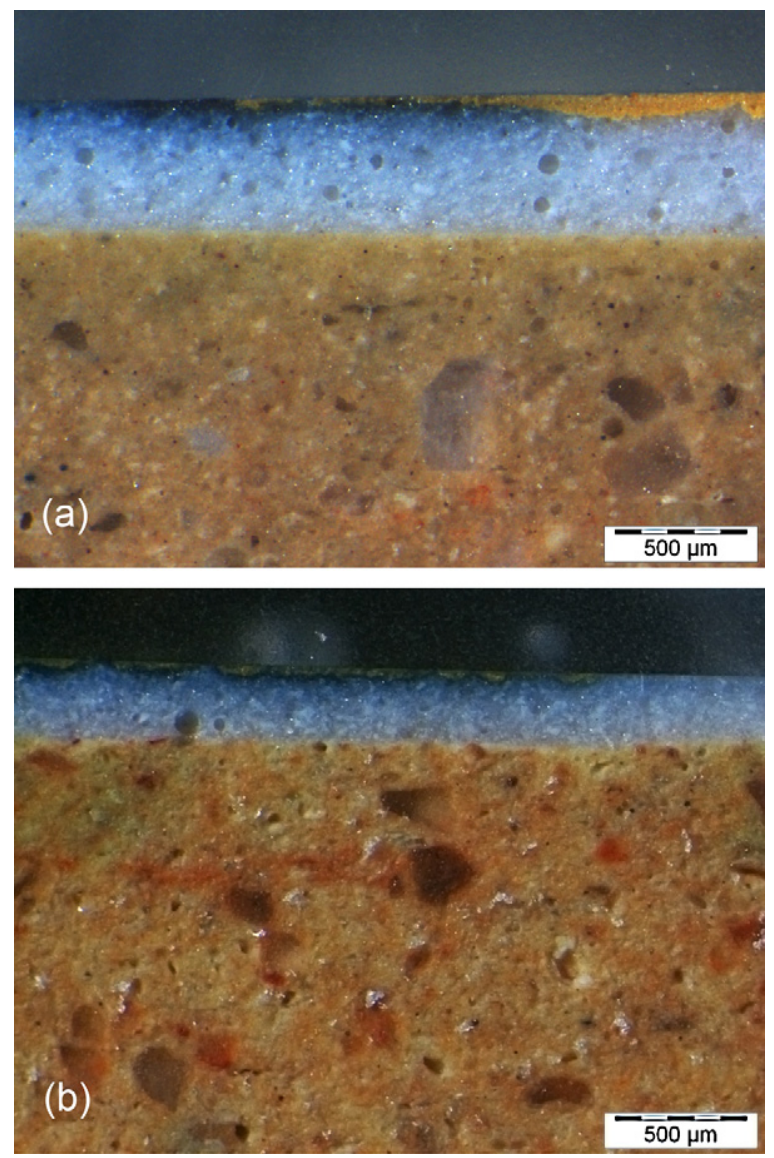

Fig. 4. Ocular lens photograph of majolica cross-sections (a) blue pigment layer, where the pigment is well diffused into the glaze, contrary to the yellow pigment layer, which remains at its surface; (b) a layer showing the olive-green colour. (For interpretation of the references to color in this figure legend, the reader is referred to the web version of the article.)

by $\mathrm{Ni}$ and $\mathrm{Fe}$, to form series that range from $100 \%$ cobalt to total substitution. ${ }^{17}$

After normalizing the peak intensities of $\mathrm{Fe}, \mathrm{Ni}$ and $\mathrm{As}$ relatively to Co (Fig. 5), samples SCT14, SCT16, SCT25 and SCT29 show a relation with the higher Fe and As contents. Samples SCT20 and SCT32 stand out as presenting a noticeably darker and extremely opaque blue shade compared to other samples. Those samples also show the strongest Ni content. Dendritic crystals, whose geometry is consistent with nickel dendrites, ${ }^{23}$ were also observed by optical microscopy on the surface of this particular blue (Fig. 6a). $\mu$-Raman analyses on these dendrites returned two types of Raman spectra. One, with a strong band at ca. $826 \mathrm{~cm}^{-1}$, enabled the identification of a cobalt olivine, $\alpha-\mathrm{Co}_{2} \mathrm{SiO}_{4}$ (Fig. 7a), as previously identified in a 17 th century Delft Plate ${ }^{24}$ and on Mastro Giorgio's majolicas. ${ }^{25}$ Another and more often recorded spectra, with two strong bands at ca. 817 and $840 \mathrm{~cm}^{-1}$, identifies a nickel olivine structure $\left(\alpha-\mathrm{Ni}_{2} \mathrm{SiO}_{4}\right)($ Fig. 7b). The first band corresponds to the $\mathrm{Si}-\mathrm{O}$ symmetric stretching band $\mathrm{A}_{\mathrm{g}}(\mathrm{Si}-\mathrm{O})_{\mathrm{s}-\mathrm{str}}$, and the second one to the $\mathrm{Si}-\mathrm{O}$ asymmetric stretching band $\mathrm{A}_{\mathrm{g}}(\mathrm{Si}-\mathrm{O})_{\mathrm{a}-\mathrm{str}} \cdot{ }^{26}$ From the few studies performed on $\mathrm{Co}$ - and $\mathrm{Ni}$-olivines there is proximity in wavenumber of the asymmetric $\mathrm{A}_{\mathrm{g}}(\mathrm{Si}-\mathrm{O})_{\mathrm{a}-\text {-str }}$ band but a decrease in wavenumber of the symmetric $\mathrm{A}_{\mathrm{g}}(\mathrm{Si}-\mathrm{O})_{\mathrm{s} \text {-str }}$ from
Ni to Co, even in a series of solid solutions. ${ }^{27}$ The Raman spectra obtained are in agreement with a Ni olivine structure and a higher content of this element corroborates this identification. Cobalt olivines have been used as ceramic pigments, but previous studies show that $\mathrm{Co}^{2+}$ ions dissolve and diffuse in the glaze matrix, giving a dark-indigo colour. ${ }^{28}$ Our samples have thick layers of the pigment, and apparently unreacted. We cannot say if this effect was intentional, considering that the use of olivines as pigments makes the production more expensive. ${ }^{29,30}$ Nickel olivines are not mentioned as traditional ceramic pigments, but as modern synthetic inorganic pigments (colour index number PG 56) and designated nickel green olivine. ${ }^{31}$ A probable cause for finding nickel olivines may be the metallurgical procedure used to refine the blue pigment. When using a cobalt source with nickel excess, it may boost the formation of a nickel olivine along with the cobalt olivine.

\subsection{Yellow colour}

As observed in the cross-sections, the yellow colour was generally painted over the other colours and remains as a layer at the surface of the glaze (Fig. 4a). The thickness of the yellow pigment layer was measured as being approximately ca. 50-100 $\mu \mathrm{m}$ for all the measured samples. Under the microscope the yellow pigment is quite heterogeneous, consisting of very light-yellow crystals, yellowish-orange crystals and some red crystals (Fig. 6b). On some samples it was possible to observe clear yellow hexagonal crystals (Fig. 6c). According to previous studies on the pigment Naples Yellow, its crystal morphology can help estimate the firing temperature of the pigment, with hexagonal crystals forming above ca. $1100^{\circ} \mathrm{C} .{ }^{32}$

$\mu$-EDXRF analyses of our samples identified, as expected, $\mathrm{Sb}$ and $\mathrm{Pb}$ in every yellow sample, consistent with the expected use of the Naples Yellow pigment. The strong intensities of the peaks in the collected spectra indicate a higher content of $\mathrm{Zn}$, when compared to the white glaze matrix. Spectra collected for the yellow pigment were not subject to subtraction of the white spectra, because of the thickness of the yellow layer.

Tin was also present, but sometimes difficult to detect, due to the weak intensities of the element peaks and also to the overlapping with $\mathrm{Sb}$ and $\mathrm{K}$ peaks (Fig. 8). The presence of $\mathrm{K}$ in the yellows is consistent with coeval recipes for the Naples Yellow pigment, ${ }^{18,33}$ which indicate the use of potash ashes as a flux.

Several studies regarding Naples Yellow and its variants have been published in the last decade, ${ }^{14,32-39}$ with particular attention given to the identification of a $\mathrm{Pb}-\mathrm{Sb}-\mathrm{Sn}$ triple oxide yellow pigment in oil painting and majolica. Picolpasso describes two yellows, a "light yellow" and a "yellow" pigment. ${ }^{18}$ The former corresponds to the yellow colour, and therefore to the pigment Naples Yellow $\left(\mathrm{Pb}_{2} \mathrm{Sb}_{2} \mathrm{O}_{7}\right)$ and the latter corresponds to the orange colour, observed in our 17th century majolica azulejos. There are three relevant references to the production of antimony yellow: Piccolpasso's treatise, an early 17 th century Italian treatise on miniature painting technique, by Valerio Mariani da Pesaro (1568-1625?), and the Darduin manuscript, a glass recipe 


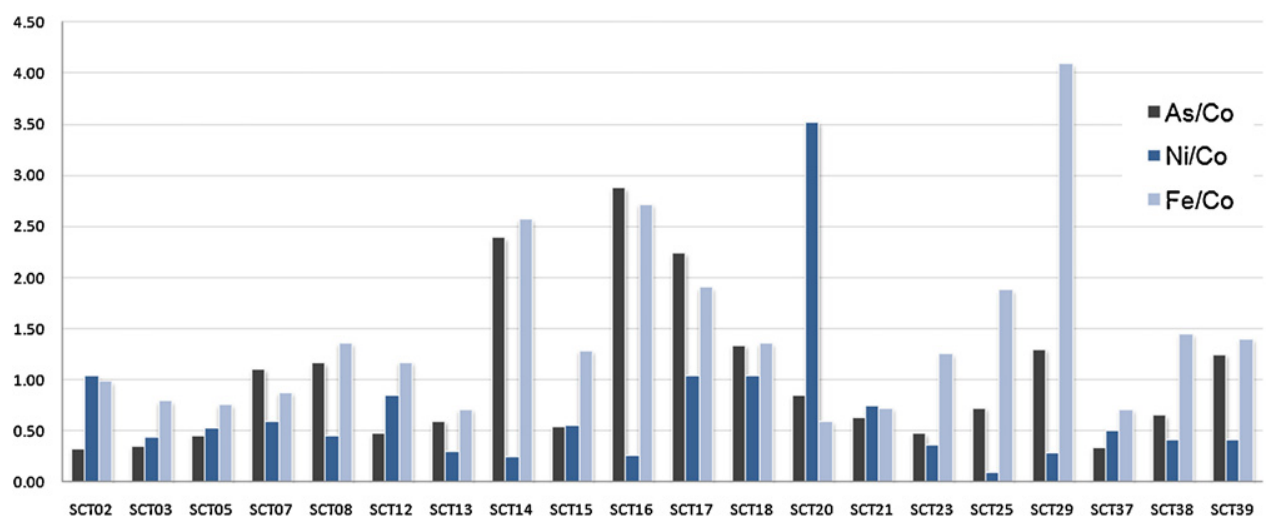

Fig. 5. Ratios of $\mathrm{As} / \mathrm{Co}, \mathrm{Ni} / \mathrm{Co}$ and $\mathrm{Fe} / \mathrm{Co}$ in the blue pigment, obtained from the peak intensities in $\mu$-EDXRF analysis.

book from the 15 th century from the workshop of the Darduin family. ${ }^{33,36}$ The three references mention the addition of an ingredient called tuttia allessandrina (or tuccia), but there is still debate on whether it refers to zinc or tin oxide. The $\mathrm{Pb}-\mathrm{Sb}-\mathrm{Zn}$ triple yellow has been identified in majolica plates dated from the 16th century and it is usually described as a darker yellow with an orange overtone. ${ }^{35}$ In our samples, $\mathrm{Zn}$ is a constant presence in all the analysed yellows.

The pigment Naples Yellow has a cubic pyrocholore structure $\left(\mathrm{A}_{2} \mathrm{~B}_{2} \mathrm{O}_{6} \mathrm{O}^{\prime}\right.$, with possible combinations of $\mathrm{A}^{2+}, \mathrm{B}^{5+}$ or $\mathrm{A}^{3+}$ and $\left.\mathrm{B}^{4+}\right)$ and is isostructural with the occurring mineral bindheimite $\left(\mathrm{Pb}_{2} \mathrm{Sb}_{2} \mathrm{O}_{6}(\mathrm{O}, \mathrm{OH})\right)$. In 1998 Roy and Berrie disclosed the usage of a modified Naples Yellow with a ternary oxide structure including lead, antimony and tin $\left(\mathrm{Pb}_{2} \mathrm{Sb}_{2-x} \mathrm{Sn}_{x} \mathrm{O}_{7-x / 2}\right)$, in 17 th century painting. Prior to this, Cascales et al. report, in
1986, the identification of a set of new pyrochlores, including the ternary oxide $\mathrm{Pb}_{2}(\mathrm{SnSb}) \mathrm{O}_{6} \cdot{ }^{40}$ Our Raman spectra are consistent with a modified pyrochlore structure identified by several authors as either $\mathrm{a} \mathrm{Pb}-\mathrm{Sb}-\mathrm{Sn}$ or $\mathrm{Pb}-\mathrm{Sb}-\mathrm{Zn}$ triple oxide, where $\mathrm{Sn}$ or $\mathrm{Zn}$ entered the pyrochlore structure substituting Sb. ${ }^{34-37}$ Spectra shown in Fig. 9 exemplify the results obtained for the yellow pigment, distinguishing three types of spectra, with the following main characteristics: very strong signals from the $\mathrm{Pb}-\mathrm{O}$ lattice vibration at low wavenumbers $\left(120-139 \mathrm{~cm}^{-1}\right)$, weaker to medium bands around between 200 and $400 \mathrm{~cm}^{-1}$ and a medium $A_{1 g}$ band at ca. $510 \mathrm{~cm}^{-1}$. When examining Fig. 9 the striking difference between spectra concern the nature and position of the strong band( $\mathrm{s}$ ) arising from the $\mathrm{Pb}-\mathrm{O}$ lattice vibration. We found indiscriminately in every yellow analysed a doublet between ca. 120 and $139 \mathrm{~cm}^{-1}$ (Fig. 9a), a strong band at ca.
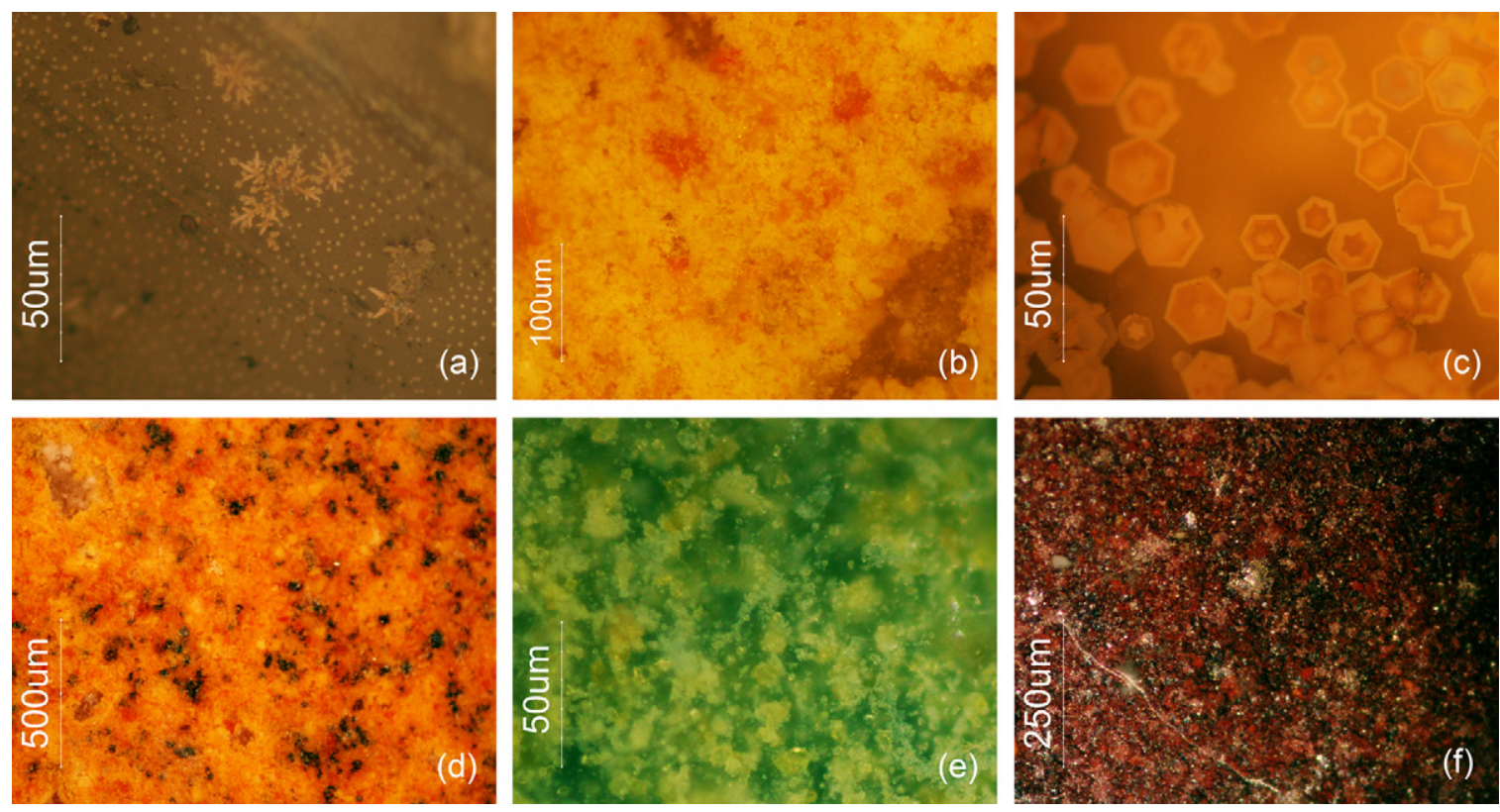

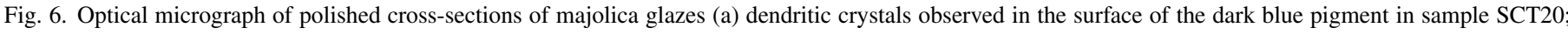

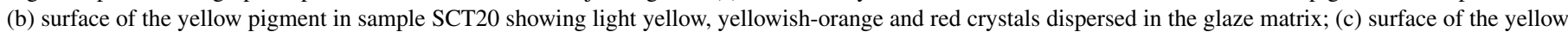

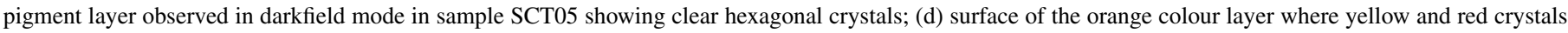

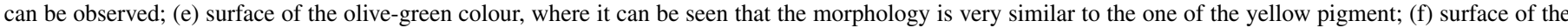

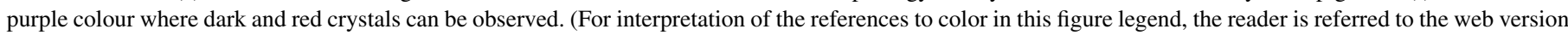
of the article.) 


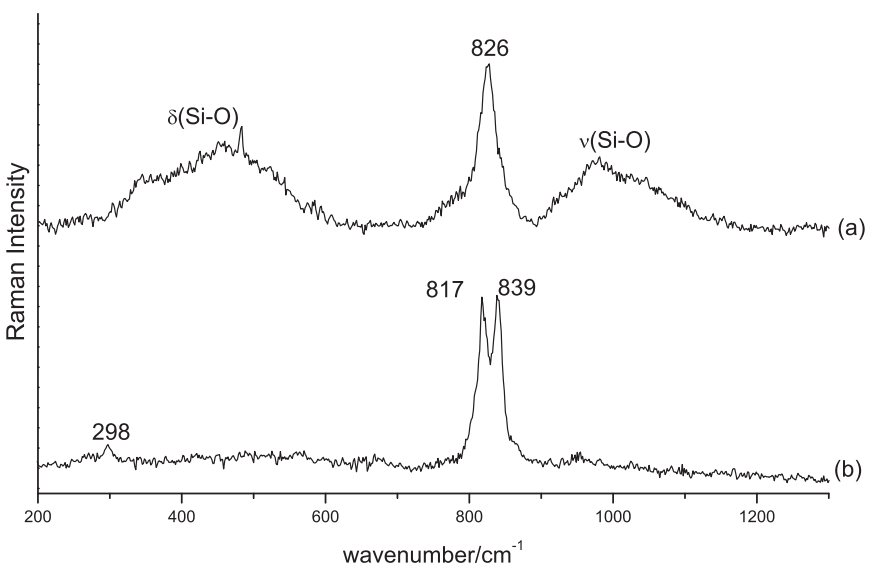

Fig. 7. $\mu$-Raman spectra of blue pigment in sample SCT20: (a) cobalt olivine $\left(\alpha-\mathrm{Co}_{2} \mathrm{SiO}_{4}\right)$ and the Raman signatures of the glass structure; (b) nickel olivine $\left(\alpha-\mathrm{Ni}_{2} \mathrm{SiO}_{4}\right)$. Laser excitation $632.8 \mathrm{~nm} ; 50 \times$ objective ULWD; laser power was kept at $1 \mathrm{~mW}$.

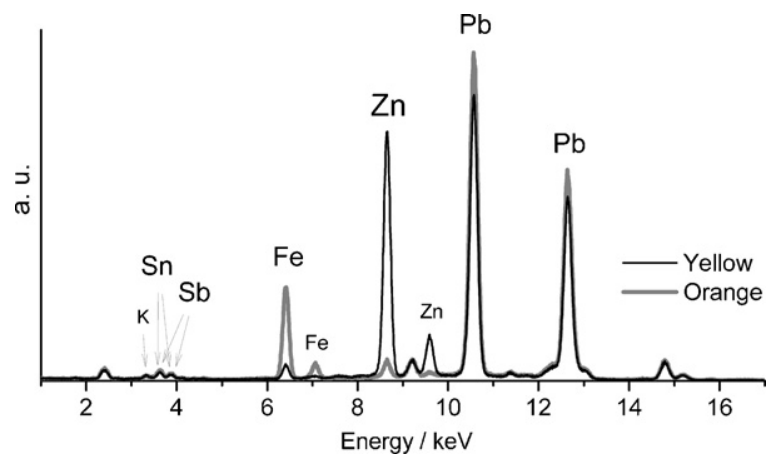

Fig. 8. Overlapping $\mu$-EDXRF spectra for the yellow and orange pigments in sample SCT05. Differences are notorious in $\mathrm{Zn}$ and Fe peaks.

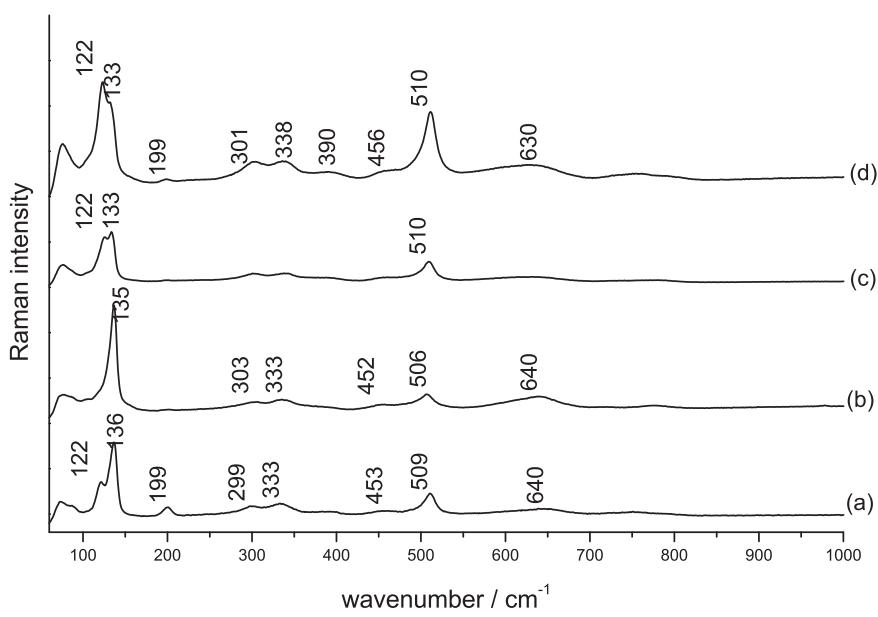

Fig. 9. $\mu$-Raman spectra of the yellow pigment showing three types of obtained spectra: (a) sample SCT 17, Raman spectrum showing a doublet between ca. $120-136 \mathrm{~cm}^{-1}$; (b) sample SCT 27 , spectrum showing a strong band at ca. $135 \mathrm{~cm}^{-1}$; (c) sample SCT 05, Raman spectrum showing a strong band at ca. $135 \mathrm{~cm}^{-1}$ with a should at ca. $122 \mathrm{~cm}^{-1}$; all wavenumbers are related to the $\mathrm{Pb}-\mathrm{O}$ lattice vibration; (d) Raman spectrum of the orange colour, focusing on the yellow crystals, and showing a spectrum similar to he yellow pigment. Laser excitation $632.8 \mathrm{~nm} ; 50 \times$ objective ULWD; laser power was kept at $1 \mathrm{~mW}$.
$135 \mathrm{~cm}^{-1}$ (Fig. 9b) or a strong band at ca. 135 with a shoulder (Fig. 9c). Previous studies assert that this band is not good for discrimination between the ternary oxides, since its intensity on the unmodified Naples Yellow also varies significantly, and can also change with the firing temperature of the pigment. ${ }^{32,34,41}$ Nonetheless, Rosi et al. observed in mock-up samples that Znmodified Naples Yellow shows a strong band at ca. $145 \mathrm{~cm}^{-1}$ and Sn-modified Naples Yellow shows a doublet at 125 and $142 \mathrm{~cm}^{-1} \cdot{ }^{34}$ We observed the three situations in every sample analysed and at different points in one sample, being unable to find a pattern for our results. The $\mathrm{A}_{1 \mathrm{~g}}$ band at ca. $510 \mathrm{~cm}^{-1}$, corresponding to the symmetric elongation of the $\mathrm{SbO}_{6}$ octahedra is considered more advantageous to discriminate the nature of the ternary oxides. Whilst on the unmodified Naples Yellow it is a strong band, it collapses and shows the emergence of a well-resolved band at ca. $450 \mathrm{~cm}^{-1}$ for the ternary oxides. For Zn-modified Naples Yellow this effect is stronger. On our samples this band shifts ca. $5 \mathrm{~cm}^{-1}$ within one sample, and the $450 \mathrm{~cm}^{-1}$ band can emerge more or less resolved, also within one sample. Finally the appearance of a band at ca. $640 \mathrm{~cm}^{-1}$ has been assigned, on one hand, as a Sn-modified Naples Yellow with silica added ${ }^{37}$ and on the other as a binary lead antimonate with Pb excess. ${ }^{34,35}$ In sum, the constant alteration on the observed main spectral signatures of the yellow pigment, even within the same sample, does not lead to an identification of which ternary yellow oxide is responsible for the yellow colour, by Raman microscopy. In contrast, $\mu$-EDXRF analyses show an intense $\mathrm{Zn}$ signal for every sample, with a small intensity signal for $\mathrm{Sn}$, suggesting a ternary $\mathrm{Zn}$ yellow oxide.

\subsection{Orange colour}

Observation of the orange coloured areas reveals a very similar appearance to the yellow-coloured ones. The colour is opaque, sometimes rough to the touch, and it remains at the surface of the glaze (also confirmed with cross-sectional observation). Through $\mathrm{OM}$, the surface of the pigment is also very similar to the yellow one, the exception being the very dark particles intertwining the yellow and orange crystals (Fig. 6d). In the orange colour, seemingly the giallo pigment described by Piccolpasso, we find our first true mixture colour, i.e., the mixture of two compounds to make a new colour.

The yellow and orange crystals were identified by $\mu$-Raman as the previously discussed yellow pigment, with a ternary oxide structure, indicating the use of the same yellow pigment in both colours. Two spectra of the yellow and orange pigments in sample SCT05 are represented in Fig. 9d, showing an identical structure. The dark particles, on the other hand, were identified as hematite $\left(\alpha-\mathrm{Fe}_{2} \mathrm{O}_{3}\right)$.

Similarities are also visible in the results from the chemical analysis through $\mu$-EDXRF and $\mu$-Raman. $\mu$-EDXRF spectra collected in the orange colour identified $\mathrm{Sb}$ and $\mathrm{Pb}$, as well as $\mathrm{Zn}$, but show a higher Fe peak intensity when compared to the spectra collected for the yellow. Fig. 8 shows two overlapped $\mu$ EDXRF spectra collected on the yellow and orange pigments for the same tile. The two spectra are identical, with the exception of 


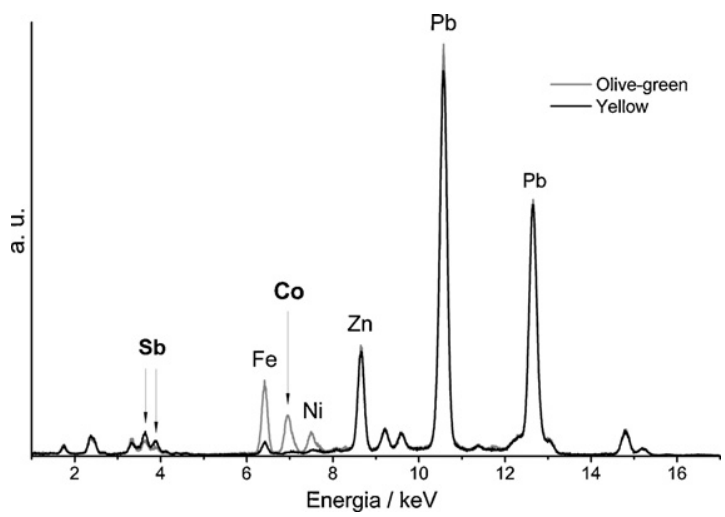

Fig. 10. Overlapping $\mu$-EDXRF spectra for the olive-green and yellow colours in sample SCT13. Cobalt and its associated elements (Fe and $\mathrm{Ni}$ ) are the main differences, revealing the mixture of two pigments (blue and yellow) to obtain the olive-green colour.

the $\mathrm{Fe}$ and $\mathrm{Zn}$ peak intensities. The Fe peak intensity is always higher in the orange colour, whereas the $\mathrm{Zn}$ content can vary significantly; when observing the spectra in Fig. 8, one can see there is a large difference in the intensity of the $\mathrm{Zn}$ peak, being much higher in the yellow pigment, but in other samples this difference was not notorious. Whilst the $\mathrm{Zn}$ is always a very important element in the yellow pigment, it sometimes shows only a very small peak in the $\mu$-EDXRF spectra for the orange colour.

The orange pigment is thus a mixture of pigments, obtained by adding iron oxide to a yellow pigment. However, in some samples, it seems that it was not the final ternary yellow pigment that was used as a basis for the orange colour. Instead, the results of the chemical analyses indicate that there was a yellow pigment used as a basis for the recipes, to which was added either iron oxide to achieve the orange tone, or and zinc oxide to obtain the final yellow pigment.

\subsection{Olive-green colour}

A green colour of an olive tone and opaque appearance is often found in Portuguese 17 th century azulejos. When observed through the optical microscope, its surface reveals a bluish-green glaze matrix in which crystals identical to the ones observed for the yellow pigment are dispersed (Fig. 6e). Cross-sections show a blue layer in the glaze matrix, corresponding to Co ions dissolved and diffused in the glaze, and a yellow layer on the surface, corresponding to the yellow pigment (Fig. 4b).

$\mu$-EDXRF analysis identified both cobalt and antimony peaks as characteristic of this green and, in some cases, a high zinc peak. As for the yellow colour, the $\mu$-EDXRF spectra collected for the olive-green is very similar to that of the yellow pigment (Fig. 10). The variation in the intensity of the $\mathrm{Zn}$ peak occurs in the same way as explained for the orange colour: in some samples it fits perfectly with the yellow spectrum and in other samples it is much weaker. Cobalt was identified in every olivegreen along with its associated elements: $\mathrm{Fe}, \mathrm{Ni}$ and As (vide Section 3.2).
$\mu$-Raman analysis on this colour returned spectra consistent with the yellow pigment (as examples see Fig. 9). It was not possible to collect a spectrum of the blue compound.

The olive-green colour is thus a mixture of the yellow and blue pigments, previously described. As happened with the orange colour, some samples show a difference in $\mathrm{Zn}$ content, indicating that the pigment used for pure yellow is different from the basis used for the mix resulting in the olive-green colour.

Picolpasso describes a "mixed green" as a mixture of a copper oxide (ramina) with the yellow pigment. ${ }^{18}$ Although this seems to be a commonly used green in Italian majolica, ${ }^{13,25}$ copper was not identified in the Portuguese olive-green. However, a mixed green resulting from blue and yellow was also used by Della Robbia's workshop. ${ }^{42}$

\subsection{Emerald-green colour}

Besides the already mentioned olive-green, another green, of an emerald tone and transparent appearance, was observed in samples SCT10 and SCT29 (Fig. 1). This emerald-green colour was identified both by $\mu$-EDXRF and $\mu$-Raman analysis to derive from a copper oxide $(\mathrm{CuO})$ dissolved in the lead-tin glaze (Fig. 11 a and b). This pigment dissolves and diffuses easily in the glaze matrix, often causing the green to spread beyond the limits of the decorative motifs. This undesirable characteristic may justify its limited use in Portuguese azulejos.

\subsection{Purple/brown/dark-brown contours}

A set of tones between a dark brown and purple are found on Portuguese 17th century azulejos both in areas of colour and in figure and motif contours (Fig. 1). The colour itself is difficult to define, due to its variability and imprecise nomenclature used in Portuguese literature concerning azulejos studies. Optical microscopy reveals a morphological distinction between the purple and the brown/dark brown colours. For the purple colour the pigment is in solution in the glaze matrix, whereas for the brown/dark brown the colour is heterogeneously distributed although mostly at the surface of the glaze. Moreover it was observed that this colour is composed of areas of a dark metallic shade and areas of a reddish colour (Fig. 6f).

SEM-EDS and $\mu$-EDXRF analysis show a manganese oxide responsible for the purple colour, as expected, and the pigment is distributed throughout the thickness of the glaze. According to $\mu$-EDXRF analysis the brown/dark brown colour not only has a high Mn peak intensity, but also contains $\mathrm{Fe}$ and $\mathrm{Ba}$. The latter was found in association with manganese in every $\mu$-EDXRF analysis whenever the Mn signal was relatively high. The presence of barium could suggest the use of the mineral psilomelane $\left(\mathrm{BaMn}^{2+} \mathrm{Mn}^{4+}{ }_{8} \mathrm{O}_{16}(\mathrm{OH})_{4}\right)$ as a source of manganese, and typically the absence of it hinted at the use of pyrolusite $\left(\beta-\mathrm{MnO}_{2}\right)$. These two manganese minerals correspond to two important and worldwide distributed manganese sources. However, Tite et al. pointed out that this assumption represents an oversimplification, pointing to the wide range of $\mathrm{Mn}$ minerals in nature, together with veins of baryte $\left(\mathrm{BaSO}_{4}\right)$ and also Ba-feldspars. ${ }^{43}$ Raman analyses of samples SCT 36, SCT 

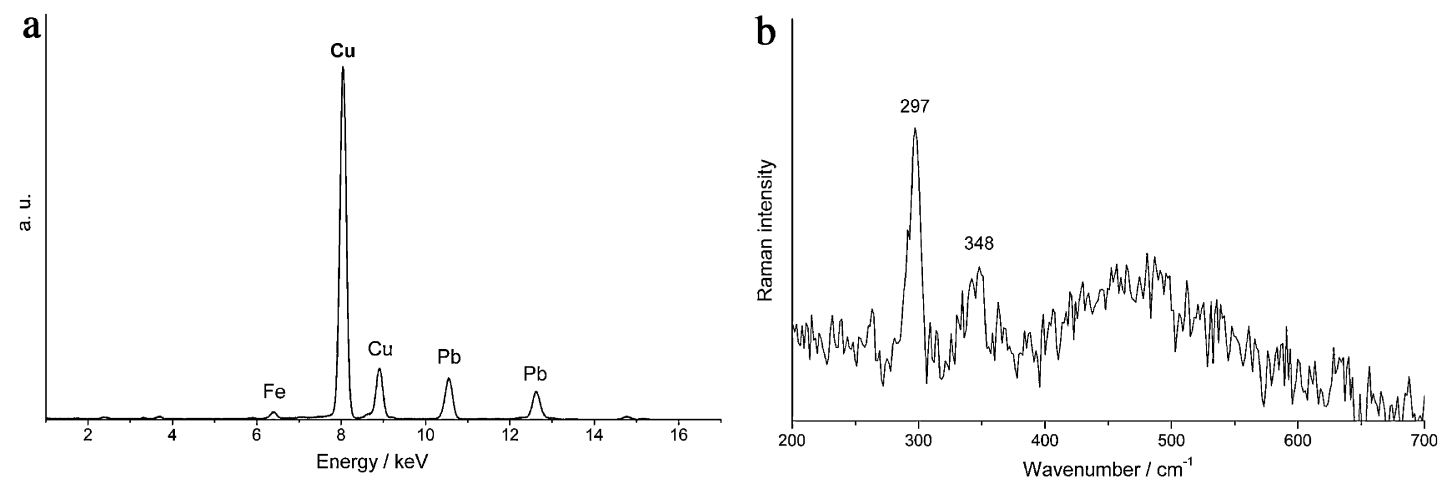

Fig. 11. (a) $\mu$-EDXRF spectrum of the emerald-green colour, with a very intense peak of copper; (b) $\mu$-Raman spectrum of copper oxide, identified in the same colour. Laser excitation, $632.8 \mathrm{~nm}$; $50 \times$ objective ULWD; laser power was kept at $1 \mathrm{~mW}$.

10 and SCT 27 revealed a different kind of manganese source to make the brown/dark pigment. The samples analysed show a distinct thick dark layer and under the microscope it is possible to observe bright hexagonal crystals. Raman spectra of those crystals show the characteristic signature of braunite, a manganese silicate $\left(\left(\mathrm{Mn}^{2+}, \mathrm{Mn}^{3+}\right)_{6} \mathrm{O}_{8} \mathrm{SiO}_{4}\right)\left(\right.$ Fig. 12a) ${ }^{44}$ Braunite is an important manganese ore along with psilomelane, pyrolusite and manganite $(\mathrm{MnO}(\mathrm{OH}))$. This $\mathrm{Mn}$ silicate usually appears in metamorphosed manganese oxide ores or in hydrothermal deposits. ${ }^{45}$ It is a common mineral in the Portuguese south region of Alentejo (where most manganese in Portugal is extracted), namely in a region known as Iberian Pyrite Belt, of hydrothermal origin. Braunite emerges here as a secondary mineral following psilomelane and pyrolusite, alongside with iron oxides such as hematite, goethite and lepidocrocite, and also baryte. In conclusion, the manganese source could be a local one. Comparing the spectra obtained for braunite with the reference spectrum from RRUFF database, our spectra is shifted to a lower wavenumber

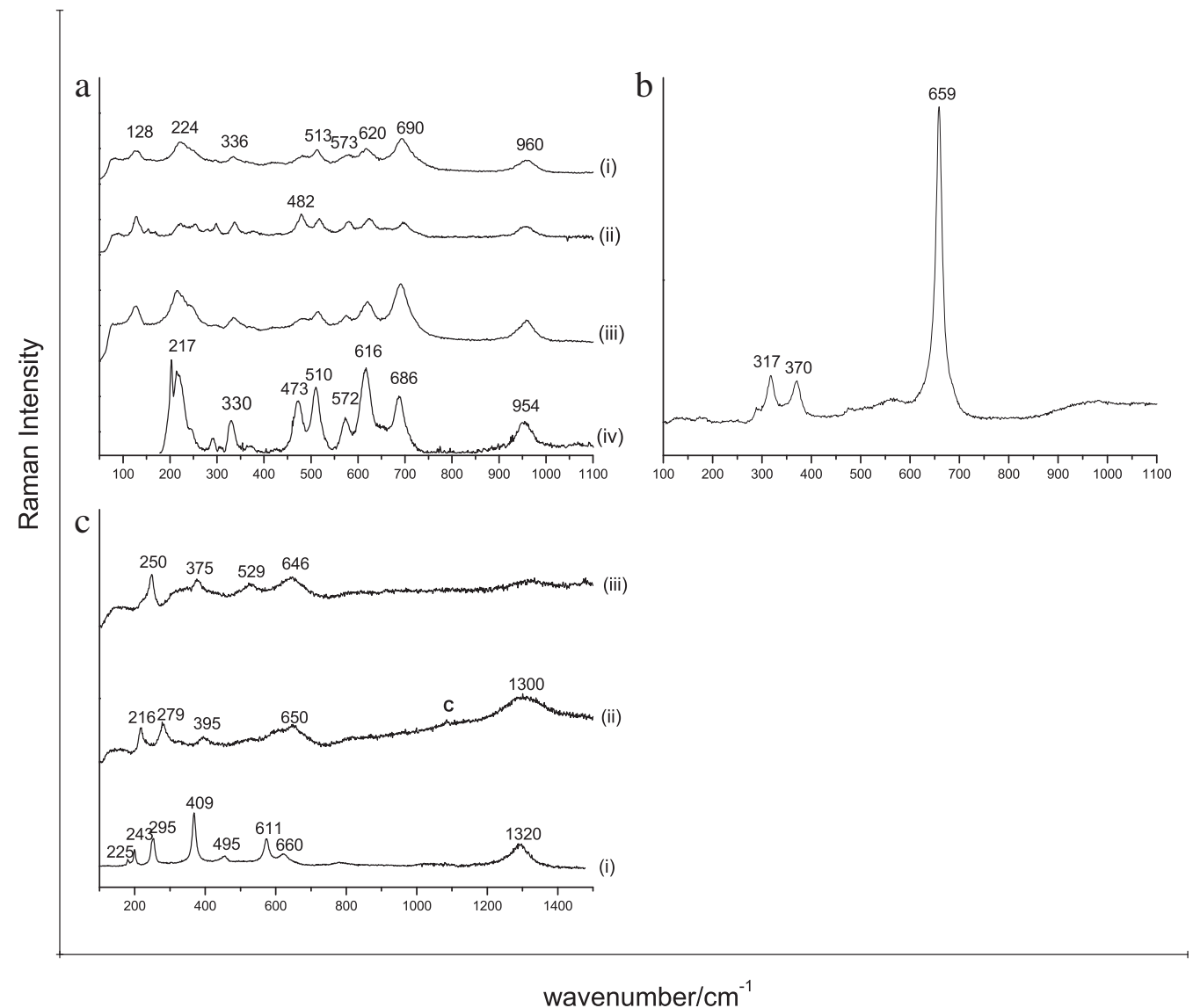

Fig. 12. (a) $\mu$-Raman spectra of braunite (a manganese silicate) identified in samples (i) SCT 36, (ii) SCT 10, (iii) SCT 27 and (iv) Reference spectrum of braunite from RRUFF project database. ${ }^{44}$ (b) $\mu$-Raman spectrum of hausmannite obtained from sample SCT 36. (c) $\mu$-Raman spectra on sample SCT 36 of (i) hematite mixed with goethite or a heated goethite structure; (ii) heated goethite structure; (iii) lepicocrocite. Laser excitation $632.8 \mathrm{~nm}$; $50 \times$ objective ULWD; laser power was kept at $1 \mathrm{~mW}$. 


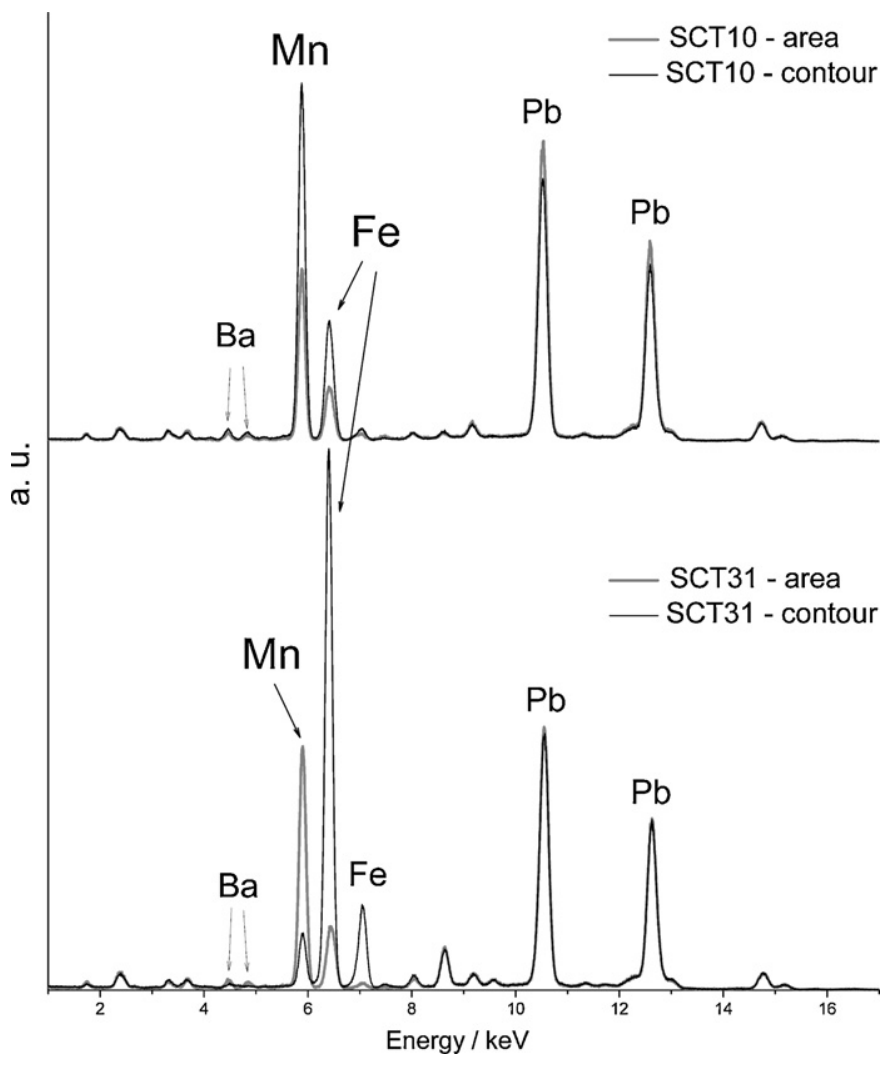

Fig. 13. Two types of purple/brown/dark-brown pigments: $\mu$-EDXRF spectra of colour areas and contours in samples SCT10 and SCT31.

ca. $6 \mathrm{~cm}^{-1}$ for every Raman band (Fig. 12a(iii)). This could be due to cation substitution in the structure of braunite, where $\mathrm{Mn}^{3+}$ can be substituted by $\mathrm{Fe}^{3+}$, and $\mathrm{Mn}^{2+}$ by $\mathrm{Mg}^{2+}, \mathrm{Ca}^{2+} \cdot{ }^{45}$ Since thermal absorption after the laser-induced heating, may lead to the formation of new mineral phases or amorphous materials ${ }^{46}$ the beam power was kept low and the consistency of the spectra was always checked at different beam powers. Analyses were performed on small particle aggregates, a procedure preferentially used for dark materials, due to strong the coupling between dark materials and the laser light. ${ }^{47,48}$

On sample SCT 36 the characteristic Raman signature of hausmannite $\left(\mathrm{Mn}^{2+}, \mathrm{Mn}^{3+}\right)_{2} \mathrm{O}_{4}$ was found, a spinel mineral with a strong $\mathrm{A}_{1 \mathrm{~g}}$ band at ca. $659 \mathrm{~cm}^{-1}$, and two other weaker bands at 370 and $317 \mathrm{~cm}^{-1}$ (Fig. 12b). ${ }^{49}$ It is also found associated with other manganese minerals such as pyrolusite and psilomelane.

Some iron oxides were as well identified by $\mu$-Raman (Fig. 12c), specifically hematite $\left(\alpha-\mathrm{Fe}_{2} \mathrm{O}_{3}\right)$, and lepidocrocite $(\gamma-\mathrm{FeOOH})$, with the typical Raman bands for each compound.$^{50}$ Hematite was often identified by itself (in the reddish colour areas) or in association with goethite (Fig. 12c(i)). This particular spectrum could also be assigned to a heated goethite structure, having a disordered hematite structure. Goethite can suffer dehydration to a hematite structure at low temperatures (ca. $260-280^{\circ} \mathrm{C}$ ), this dehydration process could have occurred here as an artefact resulting from a laser-induced heating or from the firing of the pigment in the glaze. ${ }^{51,52}$ Fig. 12c(ii) could also be assigned to the same structure of a heated goethite. Nonetheless this disordered hematite can be obtained from other factors namely grinding, biodegradation or weathering. ${ }^{51}$ Finally, lepidocrocite, found in sample SCT 27, is a common mineral found in iron ores (Fig. 12c(iii)).

$\mu$-EDXRF analysis of the colour areas and the contours identified $\mathrm{Fe}, \mathrm{Mn}$ and $\mathrm{Ba}$ (associated with the $\mathrm{Mn}$ ) as the main elements in the purple, brown and dark-brown colours. In four of seven analysed tiles, the very dark colour of the contours was achieved by a higher content of a manganese-rich pigment, whilst for the rest of the samples, the contour showed a very intense peak of iron, considerably higher than the manganese one. To the naked eye, some samples exhibit a reddish colour in the iron-rich contour, easily observed under the optical microscope as red hexagonal crystals, later identified by $\mu$-Raman as crystals of hematite. The chemical composition of the coloured areas is identical in all samples analysed, both in the purple and the brownish areas, suggesting the use of the same manganese-rich pigment. Thus, there are two types of purple/brown/dark-brown pigments used in these tiles: a manganese-rich pigment, used both for colour areas and for contours, and also an iron-rich pigment identified only in contours (a mixture of the manganese pigment and iron oxide in the form of hematite). Fig. 13 exemplifies the two cases: sample SCT10, where the same pigment was used in the colour area and in the contour, and sample SCT31, where different pigments were used.

With a multi-analytical approach it was possible to characterize the pictorial layers of 17 th century Portuguese glazed tiles (azulejos) and determine the components used to create specific colours and tones. The chemical composition of the identified colours is summarized in Table 3 .

\section{Conclusions}

Colours in 17th century Portuguese azulejos were varied in tones and chromatic effects, though obtained with a limited number of compounds: cobalt oxide, copper oxide, manganese oxide, iron oxide (as hematite) and a yellow pigment, possibly $\mathrm{a} \mathrm{Pb}-\mathrm{Sb}-\mathrm{Zn}$ ternary oxide.

Two types of colours were distinguished based on their chemical composition:

(1) the "simple" colours, where one single compound was employed, namely a metallic oxide dissolved in the glaze matrix (cobalt blue, copper green and manganese purple/brown) or, for the yellow colour, a yellow ternary oxide, possibly with a $\mathrm{Pb}-\mathrm{Sb}-\mathrm{Zn}$ structure.

(2) the "mixed" colours, which were made by mixing at least two compounds, such as the cobalt oxide mixed with the yellow synthesised pigment to give an olive-green; the yellow pigment mixed with hematite to give orange; and a manganese oxide (or silicate) with hematite to give a brown/dark colour.

Although the number of basic components was somewhat limited, the combination of at least two compounds to achieve different colours and shades lead to a richer palette available to the Azulejo painter. Yellow itself, as used in areas of pure colour by some shops, may actually have been obtained from a shop admixture of binary Naples Yellow with zinc oxide. This is a new result that may be important for provenance studies. 
Studying the pigments in Portuguese azulejos was a first step in the understanding of the techniques used by the local tile makers. We hope that in a near future a broader study will make it possible to allocate tile panels to their regions of provenance and even to specific workshops.

\section{Acknowledgments}

The research team would like to thank the National Tile Museum (Museu Nacional do Azulejo), in Lisbon, for providing most of the samples for this study. The authors would like to thank LNEC projects (PIP 17684 and 17692), and V.S.F. Muralha acknowledges the support of the Fundação para a Ciência e Tecnologia (Grant SFRH/BPD/42286/2007).

\section{References}

1. Simões JMS. Azulejaria em Portugal nos Séculos XV e XVI - Introdução Geral. 2 ${ }^{a}$ Edição Lisboa: Fundação Calouste Gulbenkian; 1990.

2. Meco J. Azulejaria Portuguesa. Lisboa: Bertrand; 1989.

3. Trindade RAA. Revestimentos Cerâmicos Portugueses. Meados do Século XIV à Primeira Metade do Século XVI. Lisboa: Edições Colibri, Faculdade de Ciências Sociais e Humanas da Universidade Nova de Lisboa; 2007.

4. Figueiredo MO, Silva TP, Veiga JP. A XANES study of the structural role of lead in glazes from decorated tiles XVI to XVIII century manufacture. Applied Physics A 2006;83:209-11.

5. Figueiredo MO, Veiga JP, Silva TP, Mirão JP, Pascarelli S. Chemistry versus phase constitution of yellow ancient tile glazes: a non-destructive insight through XAS. Nuclear Instruments and Methods in Physics Research B 2005;238:134-7.

6. Veiga JP, Figueiredo MO. A XANES study on the structural role of zinc in ancient tile glazes of Portuguese origin. X-Ray Spectrometry 2008;37:458-61.

7. Veiga JP, Figueiredo MO. Calcium in ancient glazes and glasses: a XAFS study. Applied Physics A 2008;92:229-33.

8. Pereira M, Lacerda-Aroso T, Gomes MJM, Mata A, Alves LC, Colomban $\mathrm{Ph}$. Ancient Portuguese ceramic wall tiles ("Azulejos"): characterization of the glaze and ceramic pigments. Journal of Nano Research 2009;8:79-88.

9. Carvalho AP, Vaz MF, Samora MJ, Pires J. Characterisation of ceramic pastes of portuguese ancient tiles. Materials Science Forum 2006;514(16): 1648-52.

10. Guilherme A, Coroado J, Carvalho ML. Chemical and mineralogical characterization on glazes of ceramics from Coimbra (Portugal) from the sixteenth to nineteenth centuries. Analytical and Bioanalytical Chemistry 2009;395:2051-9.

11. Guilherme A, Pessanha S, Carvalho MS, Santos J MF, Coroado J. Micro energy dispersive X-ray fluorescence analysis of polychrome lead-glazed Portuguese faiences. Spectrochimica Acta Part B 2010;65:328-33.

12. Padilla R, Schalm O, Janssens K, Arrazcaeta R, Van Espen P. Microanalytical characterizaton of surface decoration in Majolica pottery. Analytica Chimica Acta 2005;535:201-11.

13. Tite MS. The production technology of Italian maiolica: a reassessment. Journal of Archaeological Science 2009;36(10):2065-80.

14. Roy A, Berrie BH. A new lead-based yellow in the seventeenth century. In: Roy A, Smith P, editors. Painting techniques: history, materials and studio practice. London: The International institute for Conservation of Historic and Artistic Works; 1998. p. 160-5.

15. Gratuze B, Soulier I, Blet M, Vallauri L. De L'Origin Du Cobalt: Du Verre à La Céramique. Revue d'Archéomètrie 1996;20:77-94.

16. Roldán C, Coll J, Ferrero J. EDXRF analysis of blue pigments used in Valencian ceramics from the 14th century to modern times. Journal of Cultural Heritage 2006;7:134-8.

17. Zucchiatti A, Bouquillon A, Katona I, D'Alessandro A. The "Della Robbia" blue: a case study for the use of cobalt pigments in ceramics during the Italian Renaissance. Archaeometry 2006;48(1):131-52.
18. Piccolpasso C. The Tree Books of Potter's Art (Il Tre Libri Dell'Arte Del Vasaio) - A Facsimile of the Manuscript in the Victoria and Albert Museum [Translated by Alan Caiger-Smith]. London: Scolar Press; 1980.

19. Thornton D. Maiolica production in Renaissance Italy. In: Freestone I, Gaimster D, editors. Pottery in the making: world ceramic traditions. London: The Trustees of the British Museum; 1997.

20. Trindade RAA. Imagens de Azul. Revista de História da Arte: Imagem, Memória e Poder. Lisboa: Instituto de História da Arte; 2011. pp. 236-263.

21. Porter Y. Origines et diffusion du cobalt utilisé en céramique à l'époque médiévale: Etude préliminaire. In: La céramique médiévale en Méditerranée: actes du VIe congrès de l'AIECM2, Aix-en-Provence. Narration Editions: Aix-in-Provence; 1995.

22. Pérez-Arantegui J, Resano M, García-Ruiz E, Vanhaecke F, Roldán C, Ferrero J, et al. Characterization of cobalt pigments found in traditional Valencian ceramics by means of laser ablation-inductively coupled plasma mass spectrometry and portable X-ray fluorescence spectrometry. Talanta 2008;74:1271-80

23. Ferreira AF, Silva AJ, Castro JA. Simulation of the solidification of pure nickel via the phase-field method. Materials Research 2006;9(4):349-56.

24. Waal D. Micro-Raman and portable Raman spectroscopic investigation of blue pigments in selected Delft plates (17-20th century). Journal of Raman Spectroscopy 2009;40:2162-70.

25. Padeletti G, Ingo GM, Bouquillon A, Pages-Camagna S, Aucouturier M, Roehrs S, et al. First-time observation of Mastro Giorgio masterpieces by means of non-destructive techniques. Applied Physics A 2006;83:475-83.

26. Mouri T, Enami M. Raman spectroscopic study of olivine-group minerals. Journal of Mineralogical and Petrological Sciences 2008;103:100-4.

27. Lin CC. High-pressure Raman spectroscopic study of Co- and Ni-olivines. Physics and Chemistry of Minerals 2001;28:249-57.

28. Llusar M, Forés A, Badenes JA, Calbo J, Tena MA, Monrós G. Colour analysis of some cobalt-based blue pigments. Journal of the European Ceramic Society 2001;21:1121-30.

29. Bouchard M, Gambardella A. Raman microscopy study of synthetic cobalt blue spinels used in the field of art. Journal of Raman Spectroscopy 2009;41(11):1477-85.

30. Forés A, Llusar M, Badenes JA, Calbo J, Tena MA, Monrós G. Cobalt minimisation in willemite $\left(\mathrm{Co}_{x} \mathrm{Zn}_{2-x} \mathrm{SiO}_{4}\right)$ ceramic pigments. Green Chemistry 2000;2:93-100.

31. Herbst W, Hunger K. Industrial organic pigments: production, properties, applications. 3rd completely revised ed. Federal Republic of Germany: Wiley VCH; 2004.

32. Sakellariou K, Miliani C, Morresi A, Ombelli M. Spectroscopic investigation of yellow majolica glazes. Journal of Raman Spectroscopy 2004;35(1):61-7.

33. Dik J, Hermens E, Peschar R, Schenk H. Early production recipes for lead antimonate yellow in Italian art. Archaeometry 2005;47(3):593-607.

34. Rosi F, Manuali V, Miliani C, Brunetti BG, Sgamellotti A, Grygar T, et al. Raman scattering features of lead pyroantimonate compounds. Part I: XRD and Raman characterization of $\mathrm{Pb}_{2} \mathrm{Sb}_{2} \mathrm{O}_{7}$ doped with tin and zinc. Journal of Raman Spectroscopy 2009;40:107-11.

35. Rosi F, Manuali V, Grygar T, Bezdicka P, Brunetti BG, Sgamellotti A, et al. Raman scattering features of lead pyroantimonate compounds: implication for the non-invasive identification of yellow pigments on ancient ceramics. Part II. In situ characterisation of Renaissance plates by portable micro-Raman and XRF studies. Journal of Raman Spectroscopy 2011;42(3):407-14.

36. Sandalinas C, Ruiz-Moreno S, López-Gil A, Miralles J. Experimental confirmation by Raman spectroscopy of a $\mathrm{Pb}-\mathrm{Sn}-\mathrm{Sb}$ triple oxide yellow pigment in sixteenth-century Italian pottery. Journal of Raman Spectroscopy 2006;37:1146-53.

37. Sandalinas C, Ruiz-Moreno S. Lead-tin-antimony yellow: historical manufacture molecular characterization and identification in seventeenthcentury Italian paintings. Studies in Conservation 2004;49(1):41-52.

38. Seccaroni C. Giallorino: storia dei pigmenti gialli di natura sintetica. Roma: De Luca Editori d'Arte; 2006

39. Miao J, Yang B, Mu D. Identification and differentiation of opaque Chinese overglaze yellow enamels by Raman spectroscopy and supporting techniques. Archaeometry 2010;52(1):146-55. 
40. Cascales C, Alonso JA, Rasines I. The new pyrochlores $\mathrm{Pb}_{2}(\mathrm{MSb}) \mathrm{O}_{6.5}$ (M = Ti, Zr, Sn, Hf). Journal of Materials Science Letters 1986;5(6):675-7.

41. Clark RJH, Cridland L, Kariuki BM, Harris KDM, Withnall R. Synthesis, structural characterisation and Raman spectroscopy of the inorganic pigments lead tin yellow types I and II and lead antimonate yellow: their identification on medieval paintings and manuscripts. Journal of the Chemical Society, Dalton Transactions 1995;16:2577-82.

42. Sendova M, Zhelyaskov V, Scalera M, Gulliford C. Micro-Raman spectroscopy characterization of Della Robbia Glazes. Archaeometry 2007;49(4):655-64.

43. Tite MS, Maniatis Y, Kavoussanaki D, Panagiotaki M, Shortland AJ, Kirk SF. Colour in Minoan faience. Journal of Archaeological Science 2009;36:370-8.

44. RRUFF project database. http://rruff.info/braunite/display=default/ R050385 [accessed 24.02.11].

45. Bhattacharyya PK, Dasgupta S, Fukuoka M, Roy S. Geochemistry of braunite and associated phases in metamorphosed non-calcareous manganese ores of India. Contributions to Mineralogy and Petrology 1984;87:65-71.

46. Caggiani MC, Colomban $\mathrm{Ph}$. Raman identification of strongly absorbing phases: the ceramic black pigments. Journal of Raman Spectroscopy 2011;42:839-43.
47. Cvejic Z, Rakic S, Kremenovic A, Antic B, Jovalekic C, Colomban Ph. Nanosize ferrites obtained by ball milling: crystal structure, cation distribution, size-strain analysis and Raman investigation. Solid State Science 2006;8:908-15.

48. Vucinic-Vasic M, Antic B, Kremenovic A, Nikolic AS, Stoiljkovic M, Bibic $\mathrm{N}$, et al. $\mathrm{Zn} \mathrm{Ni}$ ferrite/NiO nanocomposite powder obtained from acetylacetonato complexes. Nanotechnology 2006;17:4877-84.

49. Malavasi L, Galinetto P, Mozzati MC, Azzoni CB, Flor G. Raman spectroscopy of $\mathrm{AMn}_{2} \mathrm{O}_{4}(\mathrm{~A}=\mathrm{Mn} \mathrm{Mg}$, and $\mathrm{Zn})$ spinels. Physical Chemistry Chemical Physics 2002;4:3876-80.

50. Faria DLA, Silva SV, Oliveira MT. Raman microspectroscopy of some iron oxides and oxyhydroxides. Journal of Raman Spectroscopy 1997;28:873-8.

51. Faria DLA, Lopes FN. Heated goethite and natural hematite: can Raman spectroscopy be used to differentiate them? Vibrational Spectroscopy 2007; 45:117-21.

52. Colomban Ph, Cherifi S, Despert G. Raman identification of corrosion products on automotive galvanized steel sheets. Journal of Raman Spectroscopy 2008;39:881-6. 